\title{
Alerting corporate leaders the need for ethical deliberation and sustainability
}

\author{
Umesh Sharma \\ \& \\ Martin Kelly \\ Waikato Management School \\ Private Bag 3105 \\ Hamilton 3240 \\ New Zealand \\ ups@waikato.ac.nz \\ Kelly@waikato.ac.nz
}

\begin{abstract}
In order to categorise business as "good" one must choose what characterises "Good Business". Some argue that any profitable business is good business, but profitable business sometimes creates social and environmental problems. Anyone can list what good business characteristics are, but the list will not be acceptable to everyone. We argue that, over the past sixty years, many business students and managers have been prepared to accept unquestioningly what they are told good business characteristics are, without relating those characteristics to societal and environmental wellbeing. Some decision makers have been persuaded that ethical norms associated with good living are not relevant to business decisions, except when imposed by law. Business has created many problems in society.

The Ancient Greeks chose to think carefully about the characteristics that should be encouraged in society. The results were sometimes questionable: women were not given a voice in societal decisions; the owning of slaves was acceptable. Nevertheless the decision makers of the time were required to build ethical arguments in to their decision making. In recent times business leaders have obtained huge power in society, but they have been excused building ethical considerations in to their decision models. Consequently our world is in jeopardy. Unless we build ethical considerations in to our deliberations, the world as we know it may collapse due to failures in the ecosystems, or rebellion from the huge number of intolerably poor people.
\end{abstract}

We don't believe it is possible to instruct future managers how to make correct ethical decisions, but we encourage them not to accept any extant decision model unquestioningly. Managers must install ethical considerations of their own choosing in to their decision models. Those responsible for management education must help future managers recognise the need for self-constructed ethical decision models in society.

Key words: sustainability, ethics, business, modernity, neoclassical economics, accounting education. 


\section{Alerting corporate leaders the need for ethical deliberation and sustainability}

\section{Introduction}

It is not possible to decide upon a role for business in society before deciding upon the purpose(s) of society. The purpose(s) of society are not known in any irrefutable manner. Different societies have different main purposes, for examples:

- To maximise the average wealth of members.

- To maximise the wealth of the most powerful members.

- To provide the best environment in which to practice a religious ideal.

- To allow every member to influence adopted purposes.

The list is endless but it is impossible to defend a role for business in society unless one adopts an opinion of what the purpose(s) of that society is. The role for business in society can be argued on the premise that the purpose of society should be, best to allow members of that society to live a "good life" (Sharma \& Kelly, 2015; Tinker, 2004).

Aristotle (384-322 BC) argued that the function of people is to reason how to be happy; happiness being the final target for all human endeavours. The on-going good performance of this function results in the good life (Vesey \& Foulkes, 1990). Aristotle argued that to live the good life requires ethical reasoning.

This paper discusses how "modernity" and "scientific reasoning" have encouraged many individuals to move away from ethical reasoning. This has affected what is taught in many business schools, which is often a narrow and amoral approach to decision making. This has resulted in societal and environmental problems. In recent decades these problems have become more visible. This paper suggests how we might adopt business practices which encourage citizens to live good lives.

\section{The rise of modernity}

The rise of modernity started with the renaissance in $14 / 15^{\text {th }}$ centuries. Modernity involves a belief in rationality and the triumph of truth and science over ignorance (Jary \& Jary, 1991). Since the renaissance, the natural sciences have allowed us to make huge improvements in the control of our environment, and our material well-being (aeroplanes, computers, health care, etc.). However, "Business" is a social construct and a search for scientific rules controlling its functioning is inappropriate. As Ghoshal (2005) explains, adopting beliefs in the natural sciences may be wrong e.g. the world is flat, or the sun circles the earth every day; but such incorrect understandings will not affect the true state of affairs.

Misunderstandings can be corrected in the longer term. However, if we 'discover' scientific rules that govern business in society, and everyone is persuaded to accept the rules, they will become true when everyone adopts them (e.g. agency theory). 
The accounting scandals occurring earlier this century provide many examples of meticulous rule-following to attain corporate goals, but ultimate failures because of the inadequacy of the goals and the associated rules. Transactions designed to achieve particular accounting results (e.g., transforming financing cash inflows into operating cash flows) were justified as 'consistent with accounting rules at the time' (Young \& Annisette, 2009, p.99). Employees at Enron and other energy companies developed highly favourable pricing methodologies to record 'gains' on energy derivatives (Young \& Annisette, 2009). By contrast, both Aristotelian and Confucian traditions are sceptical - if not hostile - towards actions motivated by commercial gain (Tweedie et al., 2013). Such traditions question the extent to which action motivated by commercial gain is beneficial to either the individual or society (ibid). For some, the parade of accounting scandals and unexpected company collapses in recent years has been, at least partly attributed to, the inadequacy of university curricula in accounting and business education (Amernic \& Craig, 2004).

It was recognised by some that a new 'sustainable' way of business decision making needs to evolve. Although there is no universally accepted definition of sustainable development, probably the most quoted definition is supplied by the Brundtland Commission (1987), "humanity has the ability to make development sustainable to ensure that it meets the needs of the present without comprising the ability of future generations to meet their own needs."

The recent financial crisis was shaped by over-zealous short term profit maximisation. Short-term profitability is not a sensible measure of a company's underlying health. However, the $20^{\text {th }}$ Century global economy evolved to encourage companies to focus further on short-term profitability. As Stead and Stead (2004) report:

The current economic wealth framework grew out of the Scientific and Industrial revolution that began in the seventeenth century and has since come to dominate all of society's institutions, whether they are political, religious, educational or economic..... [it] is both inaccurate and inadequate for human kind's survival (p.29).

The mental pictures that our ancestors used to comprehend their environment were developed in a very different type of world than the one that exists today... human beings developed cognitive processes that focused on the short term... For most of human history these short term mental processes were adequate for survival..... Unfortunately human perceptual processes are still tied to the old world of shortterm dramatic change (p.130).

More and more commentators are recognising that changes in the business decision making model are necessary:

The commitment to creating organisational wealth in a manner that is economically, technologically, and socially sustainable challenges conventional thinking about the nature and sources of corporate success (Post et al., 2002, p.241).

Some managers continue to think in stockholder terms because this is easier. To think in stakeholder terms increases the complexity of decision making, and it is 
overly taxing to some managers to determine which stakeholders' claims take priority in a given situation. Despite its complexity, however, the stakeholder management view is most consistent with the environment that business faces today (Caroll \& Buchholtz, 2000, p.86).

The corporate form of business needs to be redesigned to achieve greater sustainability in society (Metcalf \& Benn, 2012; Sharma \& Kelly, 2014). In 1995, the Academy of Management published a special issue that warned of the unsustainable nature of the present philosophies of business (ibid). It provided a discussion of an alternative paradigm for business, and a shift in operating practices. The objective is to develop simultaneous social, economic and ecological value creation (ibid). Since that special issue, the call for change has become more emphatic, with numerous management scholars advocating a shift in the role of business (Sharma, 2013a; Sharma \& Henriques, 2005). Contemporary accounting theory and practice depend heavily on neoclassical economics thought (Tinker, 1980). Very few scholars would deny that marginalist economics has had a significant impact on shaping accounting theory. Scholars such a Tinker (1980) and Bhaduri (1969) call for an alternative framework of political economy. Political economy differs from neoclassical (marginalist) thought in that it requires two (not one) dimensions of capital: firstly a (physical) involvement of production, and secondly a relationship amongst people in asocial organisation (Bhaduri, 1969). The first dimension involves economic forces of production, the second the social relations of production (Tinker, 1980; Metcalf \& Benn, 2012). Neoclassical economics tells only part of the story (Tinker at al., 1991). The General Motors studies (Neimark \& Tinker, 1986) focus on the various ways the company uses its annual report as an ideological weapon. The study was based on a content analysis of annual reports over 60 years; it provides a "between -the-lines" reading that uncovers the conflicting and antagonistic situation that embroiled General Motors over the period. The analysis also shows the way the firm's reports were used to modify and ameliorate these conflicts. Neoclassical economics refuses to examine basic contradictions and antinomies of the social system under investigation (Tinker et al., 1991).

Many, both inside and outside the accounting community, believe that accounting is independent and neutral in situations of conflict (Tinker et al., 1982). However, Accountants are often far from neutral in such matters (Tinker et al., 1982). Accounting has attempted to preserve objectivity and independence by shunning 'subjective' questions of value. It confines accounting data to 'objective' market price 'facts' (historical and current) (Tinker et al., 1982, p.188). This enables accountants to claim that they merely record- not partake in social conflicts. According to Tinker (2004) money seems to assume a presence that is synonymous with wealth and power; it overshadows all other qualities that may be essential to a fully-lived experience. The emphasis on profit in financial statements is a means by which capital accumulation subordinates labour.

According to Amernic and Craig (2004) accounting seems to be a language of dogmatism, class privilege; a secret society inhabited by a cognoscenti who are the only ones able to cut through the technical jargon employed (p.352). Kelly (2003) suggests we consider an alternative world without such 'class privileging'- one in which employees and stockholders change places: where labour rights are primary and explicit, and where employees make up 
the board of directors and nominate new members on such boards. Such employee perspective would feature wage and benefit data on a daily basis (an increase would be seen as a good sign; a decrease would signal a national economic downturn) (Amernic \& Craig, 2004, p.352). Share prices would not be publicly disclosed as individual shareholders would bargain for a price without knowledge of what other shareholders were paying for their shares. According to Amernic \& Craig (2004) shareholders would sometimes get no dividend and sometimes go for years without increases in dividends. This would be seen as a good thing for a company because wages would then go up more (Amernic \& Craig, 2004).

Sikka and Willmott (2002, p.194) note about accounting education:

Accounting is central to the working of capitalism. It prioritises property rights (as in a balance sheet), celebrates the supremacy of capital over labour (as in the income statement) and encourages belief in efficiency, private profits and competition..... Emphasis on its technical aspects tends to displace consideration of accounting's role in representing social conflict. Instead of posing questions about the role of education in legitimising practices that result in exploitation, poverty wages, environmental degradations and fraud, the issues become those of following the right techniques and/or accounting/auditing standards. In this way the social core of accounting becomes hidden from scrutiny.

Accounting curricula needs to encourage critique, and be served with healthy portions of scepticism (Amernic \& Craig, 2004). Accounting education needs to promote a scholarly environment in which the freedom to be critical and sceptical of conventional wisdom is encouraged.

One truth in business that scholars have been asked to realise is that managers are rational profit maximisers. This 'truth' has been repeated for many years, most persuasively by Milton Friedman (1962) and others at the Chicago Business School; many still accept it. However, as long ago as 1959 Simon, after observing how business people actually behave, introduced the concept of "bounded rationality", whereby managers are forced to impose boundaries on their decision areas because of the complexity of attempting to think holistically about problems. Such boundaries may prevent 'optimal' decisions being made, however "optimal" is defined. This rarely matters because managers will normally be safe provided their performances are considered 'satisfactory'. Thus managers "satisfice" rather than "maximise". Argyris (1990) went further in suggesting that maximisation is made even more difficult because business information is often purposely distorted by unethical individuals for their personal benefit. Baker and Bettner (1997) suggest that:

The scientific method - wherein relationships among naturally occurring phenomena are assumed to be enduring, quantifiable, and objectively 
determinable - is an incorrect paradigm that limits the perspectives for doing accounting [or business] research (p. 304).

The scientific approach to understanding business in society requires decision models to be quantified. The resultant numbers, are often based on discretionary assumptions which determine what is to be measured. They are manipulated with precise mathematical accuracy to 'prove' the correct answers to the chosen problems. Such pretence at scientific precision is foolish when the natural scientists recognise that, for example, it is impossible to know both the position and the momentum of a particle at the same time (the "Uncertainty Principle", Gribbin, 1984). The certainty sought by the 'modern' business managers is not available. Managers cannot obtain all the valid information necessary for them to make 'correct' decisions. Even if they were able to, they would generally not be able to process it all in the time available for decision making. Nonetheless those employing a scientific approach to business research have continued to recite rules for determining proper business behaviour, for example those contained in 'Agency Theory'. If enough people come to believe that all individuals in business seek to maximise their own wealth and are prepared to cheat others in order to achieve this, then business will demonstrate this awful behaviour (Ghoshal 2005).

It has been difficult for some individuals brought up in a modern society to recognise that certain behaviour in business situations is determined by human inputs coming from: intuition, spiritual beliefs, emotion and other factors. The scientific approach to business decision making requires a "calculative rationality" to be employed to ensure that businesses achieve the largest possible wealth creation. The decision makers are excused any need to employ ethical reasoning in their decision making, but they are expected to comply with the extant laws of the land. Maximising wealth becomes the only social responsibility of business managers; wealth creation is recognised as good business. Society as a whole, it is argued, can ensure that the wealth created is used to produce the best of societies for all, by distributing the created wealth appropriately. The mechanism by which this "appropriate" behaviour is governed is not well explained. However, it is explained that good business: creates employment, ensures high production of goods and services, and increases the tax take in society.

Such 'good' business, using calculative rationality, has resulted in managers behaving efficiently over many decades (Degos \& Mattesich, 2003; Sharma, 2013; Sharma \& Davey, 2013). Managers ensure that measured outputs greatly exceed measured inputs in many large corporations. The corporations, and the managers, have grown wealthy as a result of the measured efficiencies. Students in Business Schools have been educated to replicate such efficient behaviour and, some would argue, continue with good business practices that benefit society. 
Decision makers in the resultant societies make, and justify, decisions that are judged through a very narrow lens; only 'that-which-can-be-measured' matters. "Externalities" often can be measured but because these costs are not met directly by business, they too are ignored. Furthermore, in an environment freed from ethical considerations, when business models provide evidence that is unwelcome, it is possible to obtain temporary relief from the 'truth' simply by publishing evidence that is untrue. Unfortunately there have been numerous examples of such behaviour this century, see for example the numerous post-collapse articles on Enron, and the Volkswagen carbon emissions scandal exposed in 2015. Thus the models used for business decision making do not properly reflect the proper state of corporations within society. The IIRC (2011) commenting of the growing failure of the largest 500 US corporations to produce figures in their published accounts which fully explain their market value stated:

The need for a broader information set is clearly demonstrated by the small percentage of market value now explained by physical and financial assets down to only $19 \%$ in 2009 from $83 \%$ in 1975 . The remainder represents intangible factors, some of which are explained within financial statements, but many of which are not (p. 4).

Managers within wealthy corporations, that have huge asset bases, are able to conduct business efficiently. Whether their business decisions are effective in promoting a good society is questionable. To give meaning to such considerations we need to question how to measure properly the broad effectiveness of business operations in society; what is the purpose of business in society? The failure of business reports to provide an adequate basis on which to judge whether "Profitable Business" has been "Good Business" is clear; many business practices have created social and environmental problems. This matter is discussed in the following section.

\section{The recognition of business created problems in society}

In the second half of the $20^{\text {th }}$ century many people were recovering from two "World Wars". These wars had brought terrible hardships for many and the European nations had determined to do everything possible to prevent them waging war on each other ever again. Business thrived in the 1950s and 1960s. Many in the Western World believed that, "they had never had it so good". In this period the wealth and power of corporations grew substantially. Utting (2000, p. 1) reports that, "The revenues of just five corporations are more than double the GDP of the poorest 100 countries". The directors of large corporations gained more power to assign global assets to whatever purposes, than most politicians in the world have. Some individuals realised that business activities were harming the world. 'Social and Environmental Research in Business' commenced in the 1970s. It grew in strength from the 1980s onwards (Owen, 2008).

In 1983 the UN created the 'World Commission on Environment and Development' (WCED). WCED published, 'Our Common Future' in 1987. It makes the case for a paradigm shift in the way that business is carried out, in order that the viability of our world is sustained. The report developed around three central pillars: social equity, environmental protection and 
economic prosperity. It helped launch 'The Sustainable Business Movement'. Business Managers were accused of damaging the planet, and its people. In 1992 the UN organised an 'Earth Summit' in Rio de Janeiro. The summit attracted representatives from 172 governments and they signed up to 'Agenda 21', a document describing how business practices must change in order to aid the development of a healthier planet. It was agreed that a massive educational programme was required to alert the world's population to the threats being created by 'poor' business decision making, directed at immediate 'value creation' in economic terms. In 2002 a further 'Earth Summit' took place in Johannesburg. A scientific report produced for the Johannesburg Summit, Doering et al., (2002), evidenced many on-going problems. The report was extensive but the following brief excerpts illustrate its 'mood':

- The world is $78 \%$ poor, $11 \%$ middle income and $11 \%$ rich (p. 13 ).

- Nearly 26,000 plant species, more than 1,100 mammals and 1200 birds, 700 freshwater fish, and hundreds of reptiles and amphibians are threatened with extinction (p. 33).

The UN commissioned further scientific research at the start of the $21^{\text {st }}$ Century. 'The Millennium Ecosystem Assessment Report', completed in 2005, reported that:

Over the past 50 years, humans have changed ecosystems more rapidly and extensively than in any comparable period of time in human history, largely to meet rapidly growing demands for food, fresh water, timber, fiber and fuel. This has resulted in a substantial and largely irreversible loss in the diversity of life on Earth..... The changes that have been made to ecosystems have contributed to substantial net gains in human well-being and economic development, but these gains have been achieved at growing costs in the form of the degradation of many ecosystem services, increased risks of nonlinear changes, and the exacerbation of poverty for some groups of people. These problems, unless addressed, will substantially diminish the benefits that future generations obtain from ecosystems.

Problems in society are not emerging without reason. There are copious accounts of corporate misbehaviour in the literature. These provide examples of deficiencies in business reasoning. Corporations have long histories of poor ethical performance (Metcalf \& Benn, 2012; Lawrence et al., 2009; Sharma et al., 2013). Corporations were banned in England in 1720, and experienced a large public backlash in 1890, (Zerk, 2006). In modern times, corporations have committed crimes under international law, and created large scale environmental disasters (ibid). The recent global financial crisis provided further evidence of corporate misconduct. Companies collapsed due to a focus on short term profits, rather than longer-term ethically sound strategies. Companies involved included major financial institutions such as: Northern Rock, Lehman Brothers, Merrill Lynch, Fannie Mae, Freddie Mac, Merrill Lynch, Wachovia and American International Group. Critics such as Metcalf and Benn (2012) have used such examples of unethical or irresponsible practice to argue that, in its current form, the corporation is completely 'self-interested' and unable to occupy a reasonable position in a healthy society. The 'Too Big to fail' argument, whereby policy makers perceive the costs of bailout justifiable to maintain stability, actually supports bad corporate behaviour. Such bailouts evidence societal support for destructive corporate 
power (Metcalf \& Benn, 2012). The ridiculous nature of such support is obvious, and alarming. We wonder why it is tolerated.

We provide two examples of corporations' unethical practices. Firstly, the synopsis of the film The Corporation (Copyright 2003 - 2005, Big Picture Media Corporation):

The operational principles of the corporation give it a highly anti-social "personality": It is self-interested, inherently amoral, callous and deceitful; it breaches social and legal standards to get its way; it does not suffer from guilt, yet it can mimic the human qualities of empathy, caring and altruism... a disturbing diagnosis is delivered: the institutional embodiment of laissez-faire capitalism fully meets the diagnostic criteria of a "psychopath."

The film provides evidence to support the claims. Illustrations of the absences of ethical considerations in several real corporate decision scenarios are provided. Although most commentators believe that Corporations should operate within the law, the film suggest that many corporations are prepared to break the law on a cost/benefit basis. Given that breaches of the law do not always end in detection and prosecution, it is possible to estimate the likely cost of being prosecuted and set this against the proposed profit to be made from breaking the law. A huge number of large fines that have been paid by US corporations for transgressions of the law are reported. Presumably there have been many further undetected transgressions of the law that resulted in no fines, and even the large fines shown do not appear very large to the managers of wealthy corporations.

Our second example is provided by Longstaff (1992). He describes an example of decision making based on 'calculative rationality'. It illustrates that such behaviour is ethically dangerous. The example involves the Ford Motor company in the 1970s:

...the company conducted a cost-benefit analysis to determine whether or not to rectify a design fault in a vehicle. The Ford Pinto was known to be susceptible to exploding when rammed from behind. Executives sought to calculate the cost of paying damages for loss of life and for injury and then compare it with that of giving effect to a new, and safer, design (p. 7).

We trust that few in our audience would employ a calculative rationality in such a 'life-anddeath' situations. Education involving ethical and professional responsibilities is needed to ensure tomorrow's business leaders develop a framework of professional values... for exercising professional judgement and for acting in an ethical manner that is in the best interest of the public and profession (Young \& Annisette, 2009).

A related problem is that many accounting teaching staff are not formally trained in the teaching of sustainable development and ethical reasoning. They don't accept such matters as part of their teaching responsibility in their already full curricula. Despite such matters belonging at the heart of business decision making processes, many educators exclude them from their teaching programs (Tweedie et al., 2013). 


\section{Where to from here?}

If social business is to become good business the hegemony of the calculative rationality imposed on business from an economic perspective must be challenged. Students have the right to live good human lives as decided by themselves. They must decide what will be a life worth living. In doing this they will influence others in society and, we hope, encourage the adoption of good business practices that benefit society.

Rather than adopting a particular decision context and accepting what choices to make, and what rules to follow, students should learn to ask questions such as: 'who am I becoming?'; 'what does it mean to live well?' Such an alternative perspective necessitates a consideration of ethics and morality and a realisation of how they are linked to the conduct of our lives. We must encourage an ongoing and unending examination of the values we express in maintaining our daily lives (Young \& Annisette, 2009).

We argue that accounting educationalists should reject the increasingly technical/ vocational curricula that are being adopted by contemporary accounting departments (Young \& Annisette, 2009). We are convinced of the need for a fundamental restructuring not only of accounting education but business education more generally. A greater emphasis on ethics and sustainable development, should lead to classroom dialogue and critical re-examination of recent business education and managerial practices. Programmes which promote a 'deep' learning experience in accounting practice are required. Such programmes should be: interpretive, critical and analytical (Tweedie et al., 2013).

Encouraging a social view in accounting education and encouraging critique, will bring accounting from out of the shadows (Amernic \& Craig, 2004). Such changes will encourage changes in the worldview of students. Attention needs to be directed to a form of pedagogy that will help foster a new agenda for reform. Educators must be persuaded to become more open to new ways of thinking (Amernic \& Craig, 2004).

Critical accounting research is essential to reflect the limitations of neoclassical economic thought. While managers have become rigorous in their application of economic reasoning, more rigour is required in relation to social and environmental thinking. Persistently privileging the shareholder group above all other stakeholder groups is not socially just. It will encourage continuing social unrest. Future decision makers must be aware of the holistic consequences that their decision will deliver. It is imperative that business managers broaden their perspectives when making business decisions; they must ensure that ethical considerations are always present in the business decision making arena. If senior managers, and educationalists, do not realise their responsibilities in this area, the world as we know it, will be in danger. It existed for millions of years without humankind; it may return to this state again soon. 


\section{References}

Amernic, J., \& Craig, R. (2004). Reform of accounting education in the post-Enron era: Moving accounting 'out of shadows'. Abacus, 40(3), 342-377.

Argyris, C. (1990). The dilemma of implementing controls: The case of management accounting. Accounting, Organizations and Society, 15(6), 503-511.

Baker, C.R. and Bettner, M.S. (1997). Interpretive and critical research in accounting: A commentary on its absence from mainstream accounting research. Critical Perspectives on Accounting, 8, 293-310.

Bhaduri, A. (1969). On the significance of recent controversies in capital theory: A Marxian view, Economic Journal, pp.532-539.

Carroll, A.B. and Buchholtz, A.K. (2000). Business and Society: Ethics and Stakeholder Management, $4^{\text {th }}$ Edition, Cincinatti: South-Western College Publishing.

Degos, J.G. \& Mattesich, R. (2003). Accounting research in the French Language area: The first half of the $20^{\text {th }}$ Century. Review of Accounting and Finance, vol.2 (4), pp.110-128.

Doering, D., Cassara, A., Layke, C., Revenga, C., Tunstall, D. and Vanasselt, W.: 2002, Tomorrow's markets (World Resources Institute, United Nations Environment Programme and World Business Council for Sustainable Development).

Friedman, M. (1962). Capitalism and Freedom. University of Chicago Press.

Ghoshal, S. (2005). Bad management theories are destroying good management practices. Academy of Management Learning and Education, 4 (1), 75-91.

Gribbin, J. (1984). In search of Schrodinger's cat. London: Corgi.

IIRC (2011). Towards integrated accounting. International Integrated Reporting Commission.

Jary, D. \& Jary J. (1991). Dictionary of Sociology. Glasgow: HarperCollins.

Kelly, M. (2003). The Devine Right of Capital: Berrett Koehler Press.

Lawrence, S., Sharma, U., \& Nandan, R. (2009). Giving institutional theory a critical edge: a study of systems change in a Fijian housing authority. International Journal of Critical Accounting, 1(4), 390- 405.

Longstaff, S. (1992). The circuit-breaker: ethics and the limits of technique. St. James Ethics Centre Available http://www.ethics.org.au

Metcalf, L., \& Benn, S. (2012). The corporation is ailing social technology: Creating a 'fit for purpose' design for sustainability. Journal of Business Ethics, 111, 195-210.

Neimark, M. and Tinker, T. (1986). The social construction of management control systems. Accounting, Organisations and Society, vol.12 92), pp.235-266.

Owen, D. (2008). Chronicles of wasted time: A personal reflection on the current state of, and future prospects for, social and environmental accounting research. Accounting, Auditing \& Accountability Journal, 21(2), 240-267.

Post, E.J.; Lee, E.P. and Sybille, S. (2002). Redefining the Corporation, Stanford University Press.

Sharma, S., \& Henriques, I. (2005). Stakeholder influences on sustainability practices in the Canadian forest products industry. Strategic Management Journal, 26(2), 159-180.

Sharma, U. (2013). The turn in accounting and business education: Neoclassical dominance to Buddhist economics, International Journal of Critical Accounting, vol.5 (6), pp.623640.

Sharma, U. (2013a). Lessons from the global financial crisis: Bringing neoclassical and Buddhist economics theories together to progress global business decision making in the 21st century. International Journal of Critical Accounting, 5(3), 250-263. 
Sharma, U., \& Davey, H. (2013). Voluntary disclosure in the annual reports of Fijian companies. International Journal of Economics and Accounting, 4(2), 184-208.

Sharma, U., \& Kelly, M. (2014). Students' perceptions of education for sustainable development in the accounting and business curriculum at a Business School in New Zealand. Meditari Accountancy Research, 22(2), 130-148.

Sharma, U. and Kelly, M. (2015). The changing role of accounting education and management control systems in the age of sustainability, International Journal of Critical Accounting, Vol.7 (3), pp.289-303.

Sharma, U., Low, R., \& Davey, H. (2013). Developments in non-monetary disclosures in annual reports of companies: A case study. International Journal of Economics and Accounting, 4(4), 297-326.

Sikka, P., \& Willmott, H. (2002). Commentary on "Accountability of Accounting Educators and the Rhythm of the University: Resistance Strategies for Postmodern Blues'. Accounting Education: An International Journal, 11(2)

Simon, H.A. (1959, June). Theories of decision making in economics and behavioural science, The American Economic Review, 233-283.

Smith, Adam. (1838). The Wealth of Nations, Edinburgh: Black and Tait.

Stead, E.E. \& Stead, J.G. (2004). Sustainable Strategic Management. New York: Stark.

Tinker, A.M. (1980). Towards a political economy of accounting: An empirical illustrations of the Cambridge Controversies, Accounting, Organisations and Society, vol.5 (1), pp.147-160.

Tinker, A.M.; Merino, B.D. \& Neimark, M.D. (1982). The normative origins of positive theories: Ideology and accounting thought, Accounting, Organisations and Society, vol.7 (2), pp.167-200.

Tinker, T. (2001). Paper prophets: An autocritique, British Accounting Review, vol.33, pp.7789.

Tinker, T. (2004). The enlightenment and its discontents: Antinomies of Christianity, Islam and the calculative sciences, Accounting, Auditing \& Accountability Journal, vol.17 (3), pp.442-475.

Tinker, T; Neimark, M. and Lehman, C. (1991). Falling down the hole in the middle of the road" Political quietism in corporate social reporting, Accounting, Auditing \& Accountability Journal, vol.4 (2), pp.28-54.

Tweedie, D., Dyball, M. C., Hazelton, J., \& Wright, S. (2013). Teaching global ethical standards: A case and strategy for broadening the accounting ethics curriculum. Journal of Business Ethics, 1-15.

United Nations, (2005). Millennium Ecosystem Assessment. New York: United Nations.

Utting, P. (2000) 'Business responsibility for sustainable development', United Nations Research Institute for Sustainable Development, Geneva.

Vesey, G. \& Foulkes, P. (1990). Dictionary of Philosophy. Glasgow: HarperCollins.

World Commission on Environment and Development (1987) Our Common Future (The Brudtland Report), Oxford, UK: Oxford University Press.

Young, J. J., \& Annisette, M. (2009). Cultivating imagination: Ethics education and literature. Critical Perspectives on Accounting, 20, 93-109.

Zerk, J. A. (2006). Multinationals and Corporate Social Responsibility: Limitations and Opportunities in International law. New York: Cambridge University Press. 


\begin{tabular}{|c|c|c|c|}
\hline \multicolumn{4}{|c|}{$\begin{array}{l}\text { 14th Australasian Centre on Social and Envirc } \\
\text { Research Conference } \\
\text { 9-11 December } 2015\end{array}$} \\
\hline \multicolumn{4}{|c|}{ Wednesday 9 December 2015} \\
\hline $1000-1600$ & \multicolumn{3}{|c|}{$\begin{array}{l}\text { Room: } \\
\text { Emerging Scholars Colloquium led by Dr Stephanie Perkiss }\end{array}$} \\
\hline 1830-1930 & \multicolumn{3}{|c|}{ Pre-conference registration and welcome meeting at } \\
\hline \multicolumn{4}{|c|}{ Thursday 10 December 2015} \\
\hline \multicolumn{4}{|c|}{ 9:00 Registration and coffee outside the Meeting Room } \\
\hline & \multicolumn{2}{|c|}{ 9:30 Room: } & \\
\hline 9:45 & \multicolumn{3}{|c|}{$\begin{array}{c}\text { Keynote address: Charles de Villiers } \\
\text { Auckland University of Technology, New Zealand } \\
\text { "Theorising the interactions among egitimacy accountability and proactivity in the social sphere" }\end{array}$} \\
\hline \multicolumn{4}{|c|}{ 10:35 Conference splits into three streams } \\
\hline & $\begin{array}{l}\text { Room: } \\
\text { Corporate Social Responsibility } \\
\text { chair: }\end{array}$ & $\begin{array}{l}\text { Room: } \\
\text { Carbon related issues } \\
\text { Chair: }\end{array}$ & $\begin{array}{l}\text { Room: } \\
\text { Environmental accounting and sustainability } \\
\text { chair: }\end{array}$ \\
\hline & $\begin{array}{l}5 \text { Corporate social responsibility disclosure: } \\
\text { A reflection of a pilot study analysis in } \\
\text { Malaysia } \\
\text { Zaini Syeliya and Umesh Sharma, } \\
\text { University of Waikato, Hamilton, New } \\
\text { Zealand }\end{array}$ & $\begin{array}{l}\text { Carbon Management Strategy Adoption: Impact on } \\
\text { Financial and Carbon Performance } \\
\text { Yunus Somaiya, Swinburne Institute of Technology, } \\
\text { Hawthorn, Australia (Academic) ACS-016- } \\
\text { Presentation only }\end{array}$ & $\begin{array}{l}\text { The Extent of Environmental Management Accounting (EMA) } \\
\text { Implementation and Environmental Reporting (ER) Practices } \\
\text { Mokhtar Norsyahida, International Islamic University, Norhayah } \\
\text { Zulkifli and Ruzita Jusoh, University of Malaya, Malaysia } \\
\text { (Academic) ACS-012 }\end{array}$ \\
\hline 11:15 & $\begin{array}{l}5 \text { Board Diversity and CSR Reporting: } \\
\text { Australian Evidence } \\
\text { Rao Kathyayini, Flinders University } \\
\text { Business School, Adelaide and Carol Tilt, } \\
\text { University of South Australia Business } \\
\text { School, Australia (PhD) ACS-015 }\end{array}$ & $\begin{array}{l}\text { Market Reactions to Carbon-Price Legislation in } \\
\text { Australia } \\
\text { Tang Qingliang, University of Western Sydney, } \\
\text { Parramatta, Australia, Zhiwei Lin, Shenzhen } \\
\text { University, Zhijun Lin, Macau University of Science } \\
\text { and Technology and Sunny Sun, Hong Kong } \\
\text { Polytechnic University, China (Academic) ACS-026 }\end{array}$ & $\begin{array}{l}\text { CSR Monitor - A Novel Instrument for Evaluating the Quality of } \\
\text { CSR -reports } \\
\text { Sethi Satyarth Prakash, Terrence Martell and Demir Mert, } \\
\text { Baruch College, New York City, United States (Academic) ACS- } \\
051\end{array}$ \\
\hline & $\begin{array}{l}5 \text { Hedging in Foxconn Corporate Social } \\
\text { Responsibility Reports } \\
\text { Li Zhongtian and Shamima Haque, } \\
\text { Queensland of University Technology, } \\
\text { Brisbane, Australia (Academic) ACS-021 }\end{array}$ & $\begin{array}{l}\text { Towards Environmental Management Accounting } \\
\text { for Trade-offs } \\
\text { Christ Katherine, University of South Australia, } \\
\text { Adelaide, Roger Burritt, MacQuarie University and } \\
\text { Mohsen Varsei, Australian Institute of Business, } \\
\text { Australia (Academic) ACS-035 (Presentation only) }\end{array}$ & $\begin{array}{l}\text { Transitioning towards Sustainability-Based Management } \\
\text { Control Systems: A Framework for Analyzing Integrated } \\
\text { Thinking } \\
\text { Ren Chao, Gillian Vesty and Sophia Gi, RMIT University, } \\
\text { Melbourne, Australia (Academic) ACS-038 }\end{array}$ \\
\hline 12:15 & Lunch & Lunch & Lunch \\
\hline 13:15 & \multicolumn{3}{|c|}{$\begin{array}{l}\text { Keynote Presentation: Markus J. Milne } \\
\text { School of Business and Law at the University of Canterbury, New Zealand } \\
\text { "Crass Empiricism and the Social Construction of Corporate Environmental Performance" }\end{array}$} \\
\hline \multicolumn{4}{|c|}{ 13:55 Conference splits into streams } \\
\hline & $\begin{array}{l}\text { Room: } \\
\text { Education } \\
\text { Chair: }\end{array}$ & $\begin{array}{l}\text { Room: } \\
\text { Mini track on Ecological Accounts } \\
\text { Chair: Markus Milne }\end{array}$ & $\begin{array}{l}\text { Room: } \\
\text { Sustainability } \\
\text { Chair: }\end{array}$ \\
\hline 14:00 & $\begin{array}{l}\text { Exploring Students' Perspectives on } \\
\text { Ethical Elements of Social and } \\
\text { Environmental Accounting } \\
\text { Zulkifli Norhayah and Dalilawati Zainal, } \\
\text { University of Malaya, Kuala Lumpur, } \\
\text { Malaysia (Academic, Main conference) } \\
\text { ACS-013 }\end{array}$ & $\begin{array}{l}\text { Stakeholder Pressure on Carbon Emissions: } \\
\text { Strategies and the use of Management Accounting } \\
\text { Kumarasiri Jayanthi, Swinburne University of } \\
\text { Technology, Melbourne, Australia (Ecological } \\
\text { Accounts) ACS-046 }\end{array}$ & $\begin{array}{l}\text { Making sense of sustainability through resource efficiency } \\
\text { reporting } \\
\text { Egan Matthew, University of Sydney, Australia (Academic) ACs- } \\
018 \text { (Presentation only) }\end{array}$ \\
\hline $14: 30$ & $\begin{array}{l}\text { Reflections on the first two years of a } \\
\text { post graduate diploma in integrated } \\
\text { reporting } \\
\text { Swart Rene, Karin Barac and Peiter } \\
\text { Conradie, University of Pretoria, Pretoria, } \\
\text { South Africa (Academic) ACS-048 } \\
\text { (Presentation onlv) }\end{array}$ & $\begin{array}{l}\text { Ecological Accounts and Change } \\
\text { Leong Shane and James Hazelton, Macquarie } \\
\text { University, Sydney, Australia (Ecological Accounts) } \\
\text { ACS-014 (Presentation only) }\end{array}$ & $\begin{array}{l}\text { Understanding how accountants and non-accountants increase } \\
\text { their sustainability assurance work } \\
\text { Farooq Muhammad Bilal, University of Waikato, Hamilton and } \\
\text { Charles de Villiers, Auckland University of Technology, New } \\
\text { Zealand (Academic) ACS-023 (Presentation only) }\end{array}$ \\
\hline & $\begin{array}{l}\text { Presentation onlv) } \\
\text { Sociological influences on the accounting } \\
\text { curriculum: An investigation of presences } \\
\text { and absences } \\
\text { Narayanan Venkateshwaran, RMIT } \\
\text { University, Melbourne, Susan Greer, } \\
\text { Gordon Boyce, La Trobe University and } \\
\text { Bill Blair, MacQuarie University, Australia } \\
\text { (Academic) ACS-024 (Presentation only) }\end{array}$ & $\begin{array}{l}\text { Airline Constructions of Social and Environmental } \\
\text { Accounting in Brazil } \\
\text { Voss Barbara, Bruno Salotti, University of São } \\
\text { Paulo, Sao Paulo, Brazil and David Carter, University } \\
\text { of Canberra, Australia (Ecological Accounts) ACS- } \\
\text { 022 }\end{array}$ & $\begin{array}{l}\text { The Economic Consequences of Business Sustainability } \\
\text { Initiatives } \\
\text { Lau Chee Kwong, University of Nottingham Malaysia Campus, } \\
\text { Semenyih, Malaysia (Academic) ACS-027 }\end{array}$ \\
\hline 15:30 & Refreshments & Refreshments & Refreshments \\
\hline & $\begin{array}{l}\text { Room: } \\
\text { Environmental Disclosure } \\
\text { Chair: }\end{array}$ & $\begin{array}{l}\text { Room: } \\
\text { The Airline industry } \\
\text { Chair: }\end{array}$ & $\begin{array}{l}\text { Room: } \\
\text { Mini track on accounting for (in)equitable organisations and } \\
\text { societies } \\
\text { Chair: James Hazelton and Dale Tweedie }\end{array}$ \\
\hline 16:0 & $\begin{array}{l}\text { Understanding environmental disclosure } \\
\text { through the lens of stakeholder salience: } \\
\text { An exploratory case study in China } \\
\text { Qian Wei, University of South Australia, } \\
\text { Adelaide, Australia linyu Zhu, Yunnan } \\
\text { Univesity of Economics and Finance, } \\
\text { China (Academic, Main conference) ACS- } \\
\text { 044 }\end{array}$ & $\begin{array}{l}\text { The Role of Business in } 21 \text { st Century Society in } \\
\text { relation to Sustainable Development } \\
\text { Sharma Umesh and Martin Kelly, University of } \\
\text { Waikato, Hamilton, New Zealand (Academic) ACS- } \\
\text { 049 }\end{array}$ & $\begin{array}{l}\text { Religion as ethics education: toward accountability for climate } \\
\text { change induced social inequality } \\
\text { Perkiss Stephanie, Macquarie University, North Ryde, NSW, } \\
\text { Australia (Accounting for (in)equitable organisations and } \\
\text { societies) ACS-039 }\end{array}$ \\
\hline 16:30 & $\begin{array}{l}\text { The Impact of Legislative Events on } \\
\text { Corporate Greenhouse Gas Disclosure } \\
\text { Practices in Australia from 2006-2013 } \\
\text { Mia Parvez, Macquarie University, Sydney } \\
\text { and Monir Mir, University of Canberra, } \\
\text { Australia (Academic) ACS-054 }\end{array}$ & $\begin{array}{l}\text { The Role of Accounting in Legitimation and } \\
\text { Environmental Crisis: The case of Qantas (Flying } \\
\text { Kangaroo) } \\
\text { Seufert Juergen, University of Nottingham Ningbo } \\
\text { China, Brian Andrew and Anura De Zoysa, } \\
\text { University of Wollongong, Australia (Academic) ACS- } \\
045\end{array}$ & $\begin{array}{l}\text { Legitimacy versus Inequity of Accounting Language in } \\
\text { Indigenous Contexts: Exploring the Intent of language } \\
\text { Rossingh Bronwyn, Charles Darwin University, Darwin, Australia } \\
\text { (Accounting for (in)equitable organisations and societies) ACS- } \\
034\end{array}$ \\
\hline 17:00 & Close of conference day & Close of conference day & Close of conference day \\
\hline 19:00 & \multicolumn{3}{|c|}{ Conference dinner on a boat in Melbourne Harbour } \\
\hline
\end{tabular}




\begin{tabular}{|c|c|c|c|}
\hline \multicolumn{4}{|c|}{ Friday 11 December 2015} \\
\hline \multicolumn{4}{|c|}{ 8:30 Refreshments available } \\
\hline 9:00 & \multicolumn{3}{|c|}{$\begin{array}{c}\text { Room: } \\
\text { Keynote address: Helen Tregidga } \\
\text { Auckland University of Technology, New Zealand } \\
\text { "Corporate Chameleons Greenwashing and Counter Narratives" }\end{array}$} \\
\hline & $\begin{array}{l}\text { Room: } \\
\text { Corporate Disclosure and } \\
\text { reporting } \\
\text { Chair: }\end{array}$ & $\begin{array}{l}\text { Room: } \\
\text { Regional issues } \\
\text { Chair: }\end{array}$ & Room: \\
\hline 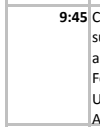 & $\begin{array}{l}\text { CSR reporting practices and the } \\
\text { substance of disclosure: An empirical } \\
\text { analysis } \\
\text { Federica Ricceri and Silvia Pilonato, } \\
\text { University of Padova, Italy (Academic) } \\
\text { ACS-058 }\end{array}$ & $\begin{array}{l}\text { Digital Financial Services and Household Accounting } \\
\text { in Rural Fiji } \\
\text { Finau Glen, Nacanieli Rika and Jale Samuwai, } \\
\text { University of the South Pacific, Suva, Fiji (Academic) } \\
\text { ACS-040 }\end{array}$ & $\begin{array}{l}\text { Labour as Capital: A small step to salience? } \\
\text { Donleavy Gabriel, UNE, Armidale, Australia (Academic) ACS-017 }\end{array}$ \\
\hline $\begin{array}{l}10: 15 \\
\text { T } \\
\text { le } \\
\text { T } \\
\text { to } \\
\text { is } \\
\text { A } \\
\text { U }\end{array}$ & $\begin{array}{l}\text { The double-edge of corporate } \\
\text { legitimating disclosure: Reactions of the } \\
\text { Tokyo Electric Power Company (TEPCO) } \\
\text { to the Fukushima nuclear accident } \\
\text { Islam Muhammad Azizul, QUT, Brisbane, } \\
\text { Australia and Azuma Kentaro, Ritsumei } \\
\text { University, Japan (Academic) ACS-037 }\end{array}$ & $\begin{array}{l}\text { Corporate Environmental Reporting (CER) in China: } \\
\text { A Stakeholder Perspective } \\
\text { Situ Hui, Pi-Shen Seet, Flinders University, Adelaide } \\
\text { and Carol Iilt, University of Suth Australia } \\
\text { (Academic) ACS-019 }\end{array}$ & $\begin{array}{l}\text { International aid NFPs and their anti-corruption disclosure } \\
\text { practices: evidence from Australia } \\
\text { Haque Shamima, Muhammad Azizul Islam, Queensland } \\
\text { University of Technology, Brisbane and David Gilchrist, Curtin } \\
\text { University, Perth, Australia (Academic, Main conference) ACS- } \\
033\end{array}$ \\
\hline 10:45 & Refreshments & Refreshments & Refreshments \\
\hline 11:15 & \multicolumn{3}{|c|}{$\begin{array}{c}\text { Professor Lee D. Parker } \\
\text { School of Accounting, RMIT University, Melbourne, Australia } \\
\text { "Accounting for CSR: Revisiting the Agenda" }\end{array}$} \\
\hline $12: 30$ & Lunch & Lunch & Lunch \\
\hline & $\begin{array}{l}\text { Room: } \\
\text { Water, Energy and Health } \\
\text { Chair: }\end{array}$ & $\begin{array}{l}\text { Room: } \\
\text { Case situations } \\
\text { Chair: }\end{array}$ & \\
\hline $\begin{array}{l}13: 30 \mathrm{~N} \\
\mathrm{~d} \\
\mathrm{p} \\
\mathrm{Z} \\
\mathrm{T} \\
\mathrm{A}\end{array}$ & $\begin{array}{l}\text { Motivation behind different level of } \\
\text { disclosure: evidence from CDP water } \\
\text { program } \\
\text { Zhang Linhan, Huiying Wu and Qingliang } \\
\text { Tang, University of Western Sydney, } \\
\text { Australia (Academic) ACS-029 }\end{array}$ & $\begin{array}{l}\text { An Understanding of Social Responsibility in a } \\
\text { Religious Organisation Context: Some Insight from } \\
\text { the Contemporary Church of England } \\
\text { Lauwo Sarah, University of Essex, Colchester, } \\
\text { Krystin Zeegan and Alan Le Grys, University of } \\
\text { KentUK (Academic) ACS-043 }\end{array}$ & \\
\hline $\begin{array}{rl}14: 00 & N \\
e & \\
F \\
c \\
0\end{array}$ & $\begin{array}{l}\text { Measuring environmental efficiency of } \\
\text { energy in OPEC countries } \\
\text { Fathi Bahram, IAU, Tehran and Mahdi } \\
\text { Chodaparast, FUM, Iran (Academic) ACS- } \\
050\end{array}$ & $\begin{array}{l}\text { Voluntary Disclosure of Negative Information in } \\
\text { Integrated Reports Issued by Japanese Companies } \\
\text { Omori Akira, Yokohama National University, } \\
\text { Yokohama and Metoki Takehiro, Musashi } \\
\text { University, Japan (Academic, Main conference) ACS- } \\
042\end{array}$ & \\
\hline 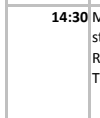 & $\begin{array}{l}\text { Moving beyond health care policies: The } \\
\text { study of public reporting } \\
\text { Rouzbehani Khadijeh, University of } \\
\text { Tehran, Iran (Academic) ACS-055 }\end{array}$ & $\begin{array}{l}\text { Italian Bank Social Report Disclosures: Level of } \\
\text { Performance Indicators } \\
\text { Guthrie James, MacQuarie University, Sydney, } \\
\text { Australia and Silvia Garavini and Daniela Sangiorgi, } \\
\text { Bologna University, Italy (Academic) ACS-053 }\end{array}$ & \\
\hline 15:00 & & $\begin{array}{c}\text { Room: } \\
\text { A summary of issues raised during th } \\
\text { Led by } \\
\text { Dr. James Hazelton }\end{array}$ & he conference \\
\hline 15:15 & & Close of Conference & \\
\hline
\end{tabular}

